\title{
The experience of application of microbiological indicators in monitoring procedures of aquatic ecosystems in the Middle Ob basin
}

\author{
Elena Shornikova ${ }^{1, *}$ and Marina Arslanova ${ }^{1,2}$ \\ ${ }^{1}$ Department of Ecology and Biophysics, Surgut State University, 628400, Lenina av. 1, Surgut, \\ Khanty-Mansi Autonomous Okrug - Ugra, Russia \\ ${ }^{2}$ Surgutneftegas PAO, Talakan Department of Technological Transport No. 1, 628400, Nefteyugansk \\ highway 7, Surgut, Khanty-Mansi Autonomous Okrug - Ugra, Russia
}

\begin{abstract}
The results of microbiological monitoring of the rivers with the various nature and intensity of anthropogenic load in the Middle $\mathrm{Ob}$ basin carried out from 2002 to 2019 is presented. The programme of monitoring included following parameters: the number of bacteria of 5 ecologicaltrophic groups, gram-staining and morphology of isolated bacteria study, testing of bacterial resistance to antibiotics and phenols. Also coefficients of mineralization and Water quality indexes were calculated. On the base of calculated values, the self-purification potential of the rivers was estimated. Studied rivers were categorized into 5 classes of water quality. In the most rivers on unpolluted and urban area $\mathrm{G}+$ and coccus forms of bacteria were predominant in the microbial community. In the rivers within oilfields the proportion of $\mathrm{G}-$ and rod-shaped bacteria was increased considerably. Seasonal and spatial distribution of resistant bacteria over the rivers allows to apply them as markers of the nature and intensity of the anthropogenic load.
\end{abstract}

\section{Introduction}

Traditionally, aquatic microbiology studies the composition of microorganisms in natural waters, their role in biogeochemical processes occurring in waterbodies. This mainly concerns the biodiversity of microorganisms, as well as the physiological processes of their growth and reproduction. There are also several branches of microbiology which study waterbodies. For example, sanitary microbiology determines whether water is safe in an epidemiological aspect. To do this, it determines the number of coliform bacteria in the water samples. But conventionally microbiological indicators are not an obligatory part of monitoring process of waterbodies. It is essential to include microbiological parameters into the monitoring programme due to the main role of microbial community in the processes of water self-purification.

Last decades a great number or researches were carried out in Eurasia in various spheres of aquatic microbiology. They were mostly situated in the eastern and central part of

${ }^{*}$ Corresponding author: capucin72@mail.ru 
Eurasia on waterbodies of high environmental or economic importance, such as the Baikal Lake [1-2], the Amur river [3-4], the reservoirs of the Volga river basin [5-8], lakes in Eastern Siberia and Mongolia [9-10] etc. The results of these studies reveal various data on the biological diversity of microorganisms and their metabolic activity, as well as trophic relationships between different groups of microorganisms in water bodies, frequently in relation to the ecological state, water quality and even pollution level. But we faced to the lack of such studies in the Western Siberia, the region of the hugest amount of transformed lakes, rivers and bogs because of oil and gas industry processes.

Our research was situated at the Middle Ob area. It is the part of the West Siberian oil and gas basin with the large territories of oilfields and related infrastructure of the biggest in Russia oil producers, such as «Surgutneftegaz», «Rosneft», «LUKoil», «Yuganskneftegas», «Salym Petroleum Development N.V.» etc. Furthermore, there are more than ten urban settlements in the Middle Ob basin; the biggest cities are Surgut, Nizhnevartovsk, Kogalym, Nefteyugansk. Therefore, the anthropogenic loading on the Middle $\mathrm{Ob}$ basin is extremely intensive. It has considerably increased from the middle of the 20 th century [11-12].

The aim of this research is to select and justify microbiological parameters to indicate the main type and level of anthropogenic transformation of waterbodies at the Middle $\mathrm{Ob}$ basin, and to reveal the direction of water self-purification processes.

\section{Materials and Methods}

The objects of our research were the rivers of the Middle Ob basin within urban areas and oilfields of Khanty-Mansi autonomous okrug - Ugra. The schematic map of the region of investigation is shown in the figure 1. Samples of water were collected in more than 100 control points during 2003-2019 on the site of the Middle Ob about $200 \mathrm{~km}$ long during various hydrological seasons.

The first step of our research was to determine the structure of the microbial community. We have chosen five ecological-trophic groups of microorganisms presented in the table 1 because of the priority pollutants of the waterbodies. Microbiological analysis was carried out using the standard in-depth Petri dish cultivation method with appropriate dilution on universal and selective media, followed by counting the number of grown colonies of microorganisms.

Table 1. The methods of studying of the structure of microbial communities.

\begin{tabular}{|c|c|}
\hline Ecological-trophic groups of bacteria & Cultivation conditions \\
\hline Total microbial number & Meat peptone agar, $25^{\circ} \mathrm{C}, 2-5$ days \\
\cline { 2 - 2 } Nitrifying bacteria & Meat peptone agar, $37^{\circ} \mathrm{C}, 24 \mathrm{~h}$. \\
\hline Coliform bacteria & Ammonium starch agar; $25^{\circ} \mathrm{C} ; 10$ days \\
\hline \multirow{2}{*}{$\begin{array}{l}\text { Hydrocarbon-oxidizing } \\
\text { bacteria }\end{array}$} & Endo culture medium; $37^{\circ} \mathrm{C} ; 24 \mathrm{~h}$. \\
\hline \multirow{2}{*}{ Phenol-utilizing bacteria } & $\begin{array}{c}\text { Liquid nutrient medium by Dianova- } \\
\text { Voroshilova; } 25^{\circ} \mathrm{C} ; 10 \text { days }\end{array}$ \\
\cline { 2 - 2 } & $\begin{array}{c}\text { Solid nutrient medium with petroleum; } \\
25^{\circ} \mathrm{C} ; 10 \text { days }\end{array}$ \\
\hline & $\begin{array}{c}\text { Solid nutrient medium by Stolbunova }+ \\
\text { phenol }\left(1 \mathrm{~g} \text { per } 1000 \mathrm{~cm}^{3} \text { of medium }\right) ; \\
25^{\circ} \mathrm{C} ; 10 \text { days. }\end{array}$ \\
\hline
\end{tabular}




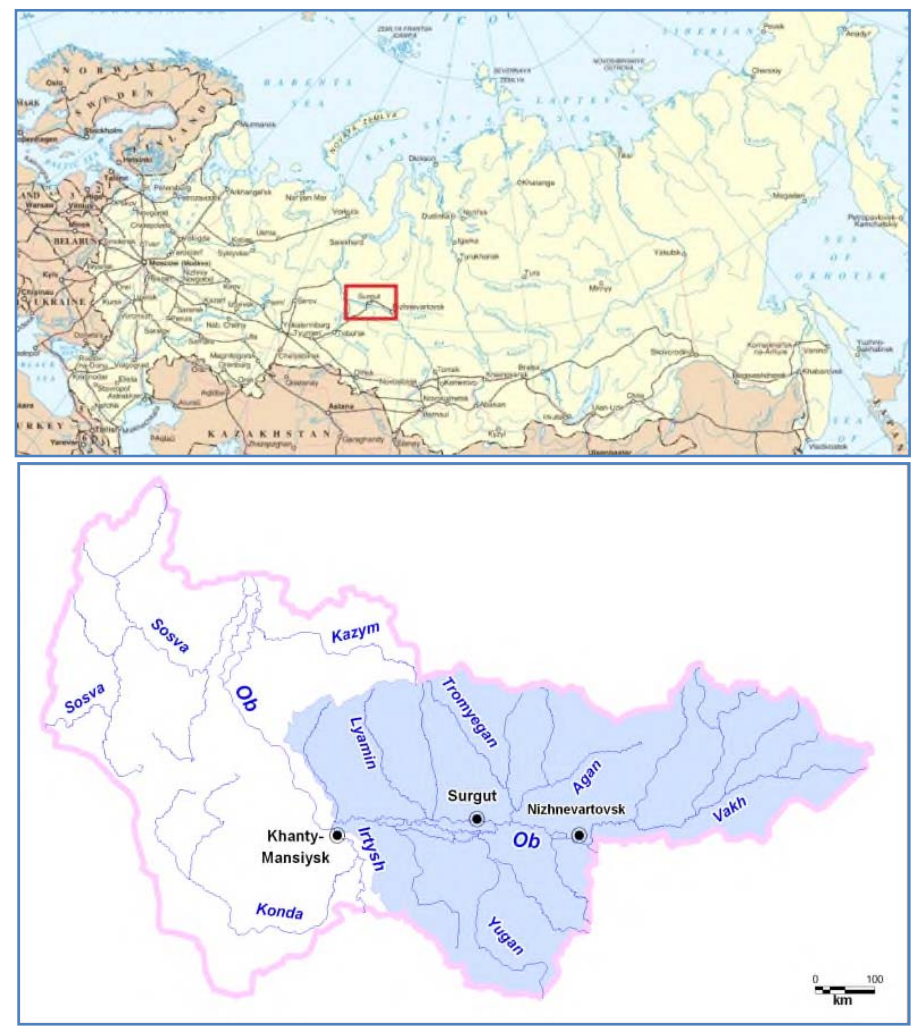

Fig. 1. The schematic map of investigated area of the Middle Ob basin within Khanti-Mansi autonomous okrug - Ugra

The ratio of the number of nitrifying bacteria $N_{N B}$ and the total microbial number $N_{T M N}$ gives us the coefficient of mineralization $C_{m}$ of organic matter in the waterbody [11]:

$$
C_{m}=N_{N B} / N_{T M N}
$$

We also calculated Water Quality Index based on the number of bacteria of various ecological-trophic groups:

$$
I_{w q}=\sum_{j=1}^{n} \alpha_{j} \cdot \frac{P_{s j}-P_{j a v}}{\sigma_{j}}
$$

$s$ - the sample point number; $j$-a controlled indicator; $P_{s j}$ the value of the indicator $j$ for the sample point $s ; P_{j a v}-$ the average value of the indicator $j$ calculated for the entire investigated water area; $\sigma_{j}$ the standard deviation of the parameter $P_{s j}$ from the average value; $\alpha_{j}$ the fraction of the parameter $P_{s j}$ in the index $I_{w q}$.

Only such parameters were included into the calculation of $I_{w q}$, for which $P_{s j} / P_{j a v}>1$. In the calculation of $\alpha_{j}$ we take $\sum \alpha_{j}=1$.

According to the obtained values of $I_{w q}$, waterbodies can be categorized to a certain class of water quality, such as:

$I_{w q}<0,5$ - relatively pure (1 class);

$0,5<I_{w q}<1,0$ - moderately polluted ( 2 class);

$1,1<I_{w q}<1,5-$ polluted (3 class);

$1,6<I_{w q}<2,0-$ heavily polluted (4 class); 
$I_{w q}>2,0-$ extremely polluted (5 class).

The second step of our study was to isolate typical colonies of bacteria of each group, to get pure bacterial cultures for further study. The morphology of cells and colonies, motility, the presence of spore formation, physiological and biochemical characteristics, Gram stain, and cultural properties were taken into account in accordance with standard microbiological methods. Identification was carried out using the manuals [13].

The third step of our experiment was to determine whether the culture of bacteria is sensible or resistant to toxic chemicals. We applied a method of determining the resistance level using disks impregnated with antibiotics with various mechanisms of action. Such as, violation of protein synthesis, violation of the cell membrane, violation of the synthesis of the cell wall of bacteria. The resistance criterion was the inhibition zone diameter on the infected Petri plate surface.

One more group of chemicals that we used in our experiment about resistance was phenols. We invented a method for determining the resistance of bacteria to phenol using disks impregnated with phenol solutions in various concentrations.

\section{Results and discussion}

\subsection{The structure of microbial community}

The examples of the structure of aquatic microbial communities of rivers of the Middle $\mathrm{Ob}$ basin during various hydrological seasons are presented in the figure 2 . In general, the number of bacteria demonstrates the difference in samples collected in various hydrological seasons. It depends on abiotic factors mostly, such as ice cover, temperature of water and oxygen saturation. The number of bacteria naturally decreases in the under ice period.

The first group in the microbial community structure is the total microbial number. This group includes the total number of saprophytic bacteria; it indicates the trophic state of the waterbody. The representatives of 7 genuses of bacteria (Pseudomonas sp., Azomonas sp., Alcaligenes sp., Bacillus sp., Sarcina sp., Micrococcus sp., Planococcus sp.) were identified among microorganisms of this group [14].

The second group is nitrifying bacteria using mineral forms of nitrogen and polymer substrates. The representatives of 2 genuses of bacteria (Nitrosomonas sp., Nitrobacter $s p$.) were identified. After counting $\mathrm{C}_{\mathrm{m}}$ we revealed that only $23 \%$ of rivers had acceptable capacity of self-purification. If the coefficient is below 1 , the intensity of self-purification of water is not sufficient, and organic matter accumulates in the waterbody. Mostly the coefficient has peaked in the high water period. Interestingly, that the highest intensity of self-purification was appeared in transformed rivers within urban areas and oilfields.

The third group is coliform bacteria; it indicates faecal pollution of the water body. Then we counted the proportion of coliform bacteria in the total microbial number. It indicates whether water is a source of intestinal infections. The highest number of coliform bacteria with the proportion $50 \%$ and more in the total microbial number was discovered in $13 \%$ of samples, especially within urban areas in the low water period.

The forth group is hydrocarbon-oxidizing bacteria. This group was chosen because the most important industrial activity in the Middle $\mathrm{Ob}$ region is oil production, refining and transportation. Thus, oil hydrocarbons from the oilfields and pipelines are the main pollutants of waterbodies. The representatives of Artrobacter sp., Actinomyces sp., Rhodococcus $s p$. were identified among the hydrocarbon-oxidizing bacteria. 

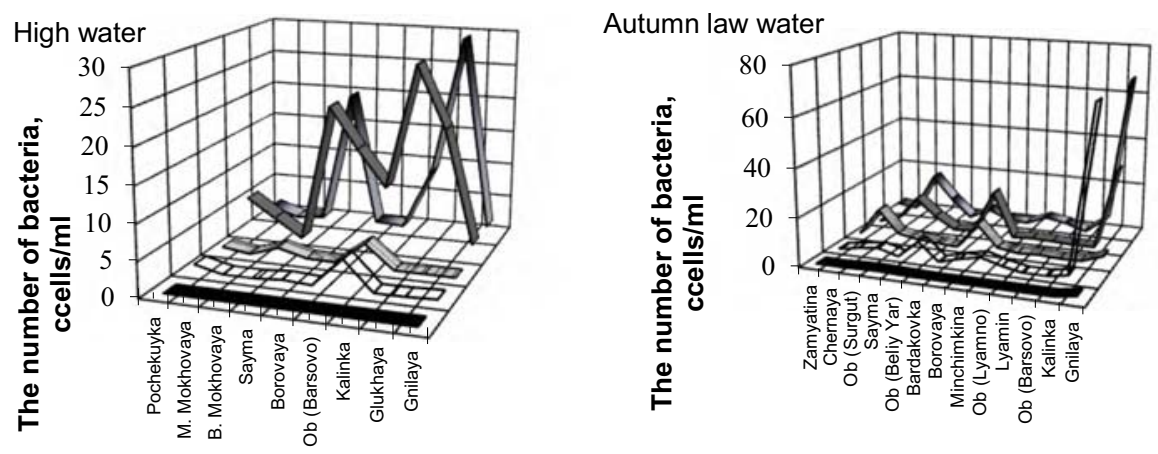

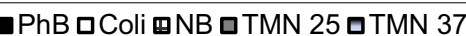

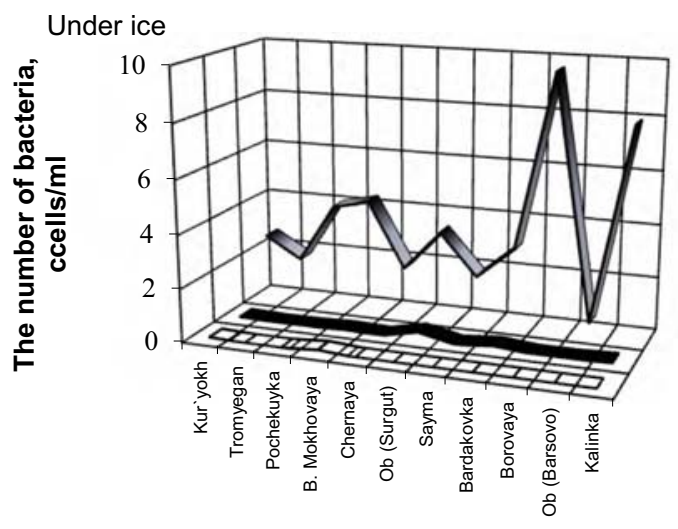

Fig. 2. The structure of microbial communities of rivers of the Middle $\mathrm{Ob}$ basin.

And the last group is phenol utilizing bacteria. Phenols are often present in waterbodies as crude oil components, as well as decomposition products of plant and wood residues. We detected the representatives of Methylobacterium sp., Acetobacterium sp., Flavobacterium $s p$., Dienococcus $s p$. in this group. As a result, the number of bacteria in these two groups has reflected the level of influence of the oil and gas industrial activity on the waterbodies.

\subsection{Water quality index}

The results of the water quality index calculation and distribution of rivers with different nature of anthropogenic load to categories of water quality according to the microbial community structure parameters are presented in the figure 3. Among the studied rivers, the $\mathrm{Ob}$ river in Surgut region (the village of Lyamina and the village of Barsovo), its large tributaries, such as the Lyamin, Pim, Trom'egan, Bolshoy Balyk, Bolshoi Yugan rivers, as well as small rivers within the urban area of Surgut, were assigned to the 1st class "pure". It should be mentioned that all rivers within unpolluted areas, such as the Bolshoy Yugan river in the territory of the National reserve "Yuganskii», by the number of bacteria were classified as "pure". 13 rivers, mostly under industrial pressure, were assigned to the 5th class "heavily polluted". 


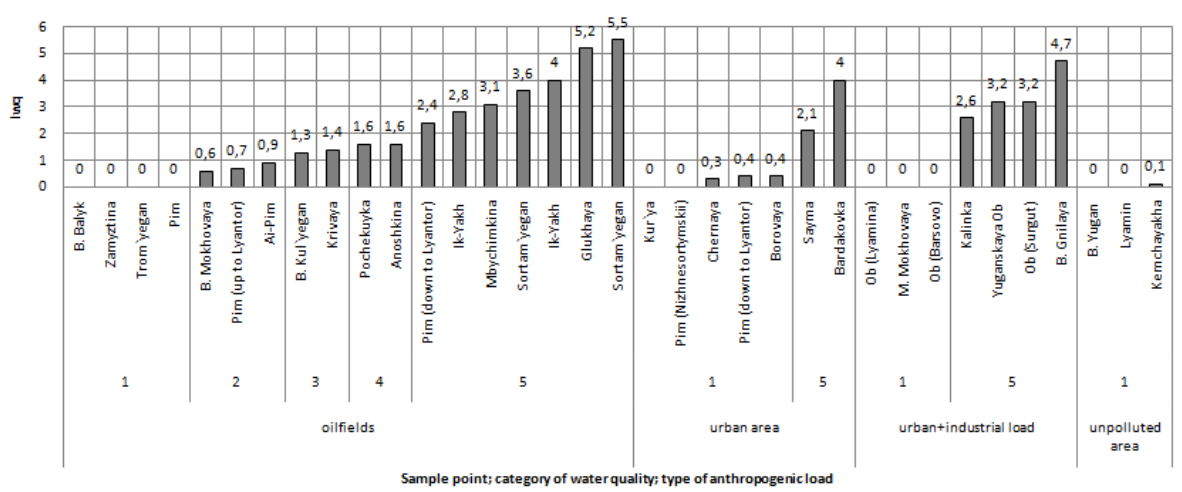

Fig. 3. Water quality index calculated on the base of microbial community structure parameters

\subsection{Gram staining results and morphological characteristics of isolated bacteria}

Such ordinary procedures as Gram staining and research of bacterial cells morphology can also reveal the intensity of anthropogenic pressure. For example, in unpolluted waterbodies $\mathrm{G}+$ forms of bacteria prevail; an increase in the proportion of $\mathrm{G}-$ forms indicates anthropogenic pressure on the water ecosystem. The ratio of morphological forms of bacteria is also the indicator of the level of organic pollution of the waterbody. So, at the final stages of the decomposition of organic matter, coccus forms predominate, a high number of rod-shaped forms of bacteria indicates a large amount of hardly decomposable organic matter.

We confirmed this phenomenon in the course of our study. The results of Gram stain and morphology research is presented in the figure 4. All the rivers in unpolluted territory were characterized by a predominance of $\mathrm{G}+$ bacteria isolates. Coccus forms prevailed in the samples from the Bolshoi Yugan and Lyamin rivers. Similar results were detected in the majority of rivers on urban area and in the river Bolshaya Gnilaya with the mixed urban and industrial type of anthropogenic load.

Concerning to the rivers within oilfields, about $47 \%$ of the rivers demonstrated the predominance of $\mathrm{G}-$, and $63 \%$ - of rod-cells forms of bacteria isolates respectively. The largest number of gram-negative isolates was found in the Yak'yavin, Komar'ya, Vynga, Ai-Pim and Zamyatina rivers. The maximum of rod-cells was detected in the Minchimkina, Ai-Pim, Vynga and Viris 'yavin rivers.

\subsection{Resistance of isolated bacteria to antibiotics and phenols}

The results of a study of the resistance of isolated bacteria to antibiotics and phenols are presented in figure $5.75 \%$ of the tested bacteria isolated from the rivers on unpolluted areas were sensitive to antibiotics. Whereas on transformed rivers, an increase in the proportion of resistant bacteria was revealed, up to $44-54 \%$ in the rivers within oilfields and up to 86 $93 \%$ in urban area. This phenomenon was most pronounced on urbanized rivers during the flood period. It should also be mentioned a high proportion of polyresistant bacterial cultures that were resistant to several antibacterial chemicals with different mechanisms of action, in rivers on residential areas, up to $65 \%$ in the under ice period. Obviously, it could be explained by the widespread use of antibiotics in contemporary medicine with the subsequent formation of resistant forms of bacteria, their release into the environment and transfer to rivers with wastewater [15]. 


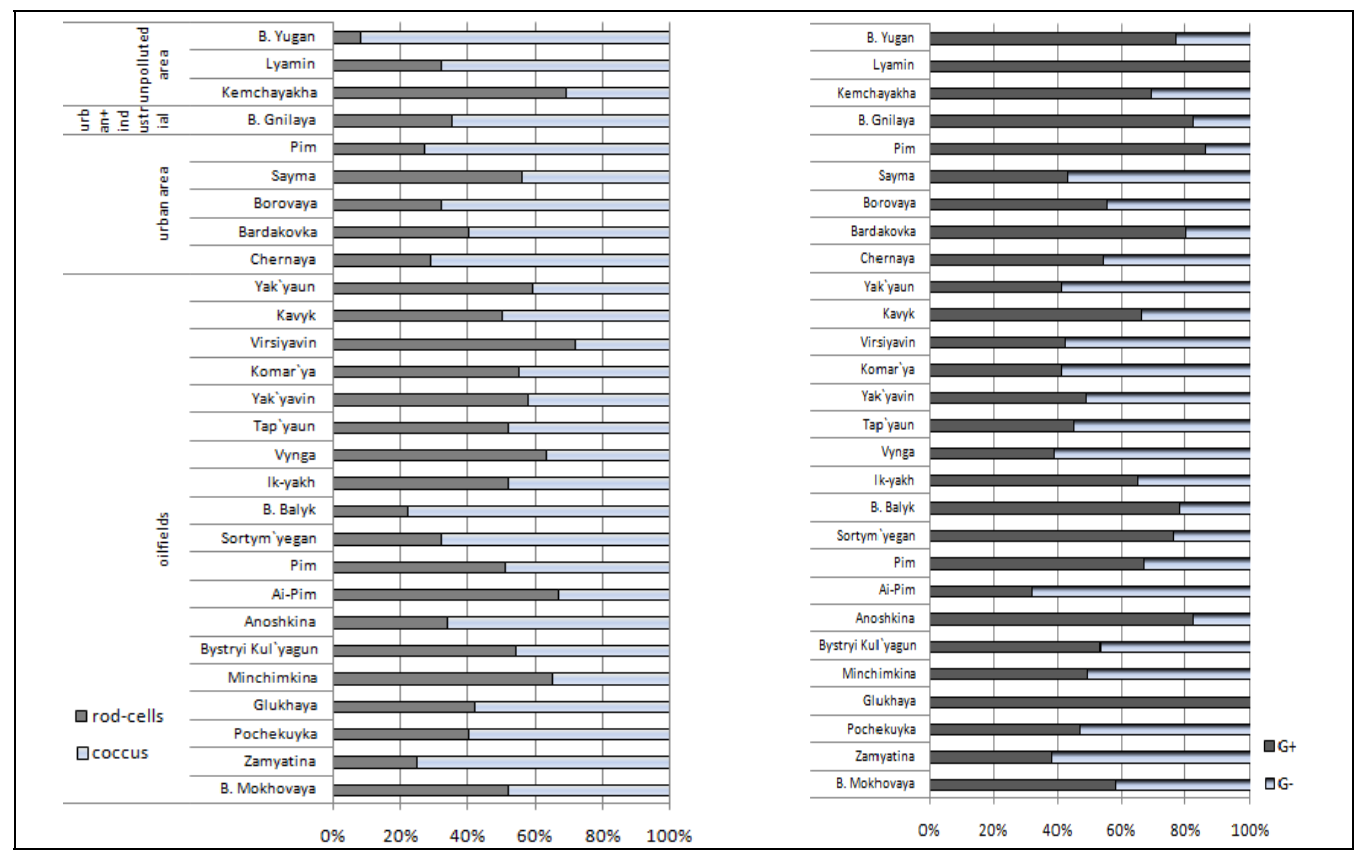

Fig. 4. Water quality index calculated on the base of microbial community structure parameters

\section{Antibiotic resistance}

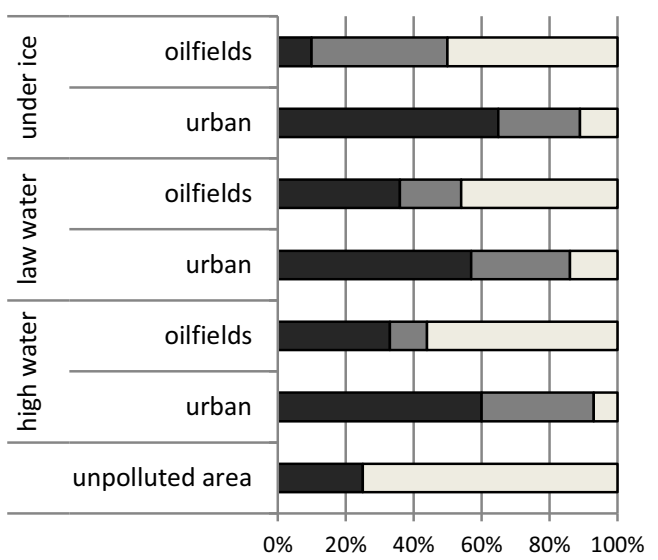

$\square$ poly-resistant $\square$ mono-resistant $\square$ sensitive

\section{Phenol resistance}

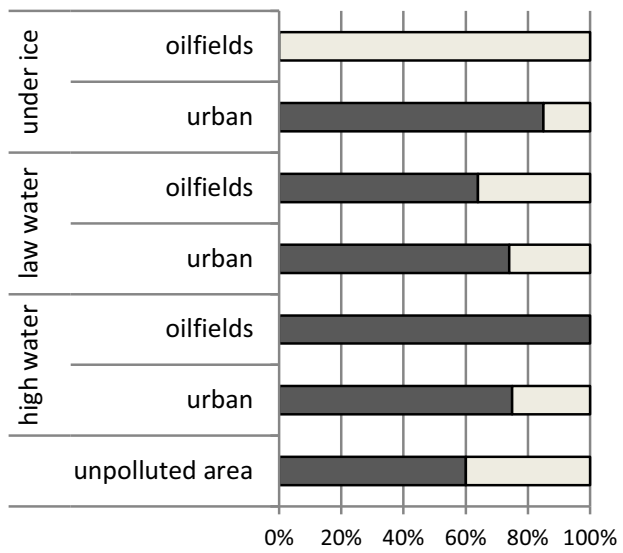

$\square$ resisnant $\square$ sensitive

Fig. 5. Test results of bacterial resistance to antibiotics and phenols

However, we also observed a high level of bacterial resistance in the rivers within the oilfields. This may be caused by the applying of antibacterial components in drilling fluids composition in oil production technologies in order to prevent biological corrosion of equipment.

Concerning to phenol resistance of bacteria, we discovered resistant bacteria cultures in all types of the rivers, even on unpolluted area, with the exception of the rivers within oilfields during under ice period. This suggests the most likely way for the formation of 
bacterial resistance to phenols in the catchment area surface during the open water period with subsequent entry into the rivers. An absolute phenol-resistant properties of all isolated bacteria cultures from rivers within the oilfields during high water period was also discovered. That's why we consider the oil production processes to be one of the source of forming of phenol resistance of bacteria.

The authors are grateful to V.N. Tyurin for his help in compiling the maps of the investigated part of the Middle Ob basin, and also to E.P. Perlova for research assistance.

\section{Conclusion}

Five ecological-trophic groups of bacteria have been demonstrated as effective indicators of the ecological state of the rivers and intensity of anthropogenic load. Most of the studied rivers were characterized by the low self-purification potential, which was confirmed by low mineralization coefficients and the presence of phenol-utilizing bacteria in the samples.

The studied rivers were categorized into 5 classes of water quality according to the quantative structure of microbial community. The pure rivers were identified on unpolluted catchment area.

In the most rivers on unpolluted and urban area gram-positive and coccus forms of bacteria were predominant in the microbial community. The predominance of the rod-cells bacteria was revealed in $63 \%$; G- bacteria - in $47 \%$ of samples collected from the rivers within oilfields.

The distribution of antibiotic-resistant bacteria over the rivers, as well as the seasonality of their isolation, allows to apply them as markers of the nature and intensity of the anthropogenic load. The higher intensity of the anthropogenic load on the river is observed, the greater proportion of resistant bacteria in the microbial community is revealed.

Phenol resistance of bacteria is formed during the high water period, mainly on the catchments of rivers with anthropogenic pressure.

\section{References}

1. E. V. Lavrentyeva, A. A. Radnagurueva, D. D. Barkhutova et al., Microbiology, 87, 272-281 (2018) doi:10.1134/S0026261718020078

2. E. V. Lavrentyeva, T. G. Banzaraktsaeva, A. A. Radnagurueva et al., Contemp. Probl. Ecol. 12, 584-593 (2019) doi:10.1134/S1995425519060088

3. L. M. Kondrateva, Z. N. Litvinenko, Resources, Environment and Regional Sustainable Development in Northeast Asia. Proceed. of 2nd Int. Conf., Changchun, China, 48 (2015)

4. L. M. Kondratyeva, N. K. Fisher, V. V. Bardyuk, Contemp.Probl. Ecol., 5, 185-190 (2012) doi:10.1134/S1995425512020072

5. A. I. Kopylov, D. B. Kosolapov, I. V. Rybakova, Water Res., 46, 45-51 (2019) doi:10.1134/S0097807819010093

6. A. I. Kopylov, D. B. Kosolapov, V. I. Lazareva, Inland Wat. Biol., 11, 237-244 (2018) doi:10.1134/S1995082918030082

7. A. I. Kopylov, D. B. Kosolapov, E. A. Zabotkina, N. G. Kosolapova, Contemp. Probl. Ecol. 9, 297-305 (2016) doi:10.1134/S1995425516030082

8. D. B. Kosolapov, N. G. Kosolapova, E. V. Rumyantseva, Biol. Bul.1 Russ. Acad. Sci. 41, 324-332 (2014) doi:10.1134/S1062359014040050 
9. Y. T. Wu, C. Y. Yang, P. W. Chiang, C. H. Tseng, H. H. Chiu, B. Baatar, S. L. Tang, I. Saeed, S. Halgamuge, D. Rogozin, A. Degermendzhi, Front in Microbiol. 9/JUL, 1763 (2018)

10. D. Y. Rogozin, V. V. Zykov, M. O. Tarnovsky, Microbiol., 85, 93-101 (2016) doi:10.1134/S0026261716010100

11. E. A. Shornikova, Contemp. Probl. Ecol., 1, 328-334 (2008) doi:10.1134/S1995425508030077

12. S. N. Rusak, E.A. Shornikova, M. I. Kurilenko, T I Homenushko, IOP Conf. Ser.: Earth Environ. Sci., 400, 012018 (2019) doi:10.1088/1755-1315/400/1/012018

13. Bergey's Manual of Systematic Bacteriology. Springer-Verlag (New York, 2010) doi:10.1007/978-0-387-68572-4

14. M. M. Arslanova, E. A. Shornikova, Limnol. And Freshwat. Biol., 4, 961-962 (2020) doi:10.31951/2658-3518-2020-A-4-961

15. M. Woegerbauer, X. Bellanger, C. Merlin, Front. in Microbiol. 11, 671 (2020) doi:10.3389/fmicb.2020.00671 